$\xi=-1$

\title{
Human Governance: The Art of Emotional Intelligence of Leader Through the Model of Spirituality
}

\author{
Siti Sarawati ${ }^{1}$ \\ ${ }^{1}$ Centre For General Studies And Cocurricular, University Tun Hussein Onn Malaysia, Johor, Malaysia \\ *Corresponding Author E-Mail: Sarawati@Uthm.Edu.My
}

\begin{abstract}
This paper is a concept paper which is focused on the discussion about the emotional intelligence of leader in the human governance elements at the workplace from the perspectives of the spirituality model. These are the claims of reality the management application which is based of religion and science as well as browse the dimension of emotional in organizations today. This discussion encompasses the conceptual of emotional intelligence, human governance and spirituality model; application needs; challenges and hopes. In line with the demands of human capital development, supposed the physical development and materially advanced with that momentum growing over the years in tandem with human development. We not only want the country to have a first-class facility, but most important are the mentality, spiritual and behaviour first class which is oriented of human capital. The synonyms here, each employee in any organization as a human entity are should be the ideal capacity of human capital in terms of emotional intelligence to produce the quality work and have a strong human governance. To that end, leaders in the workplace should have a high level of emotional intelligence to form a positive culture among employees and create practices that are consistent so that it can become a habit that is conducive to all parties in the working environment. The end of this paper will demonstrate the need for all leaders to have the emotional intelligence with spiritual strength and lead a more meaningful behaviour. It would also allow employees to perform a dynamic human capital and thus able to establish a framework of a major platform in the management and human governance characterized by spirituality trait in their work.
\end{abstract}

Keywords: Emotional Intelligence, Leader, Human Governance, Spirituality Model

\section{Introduction}

Lately, the term of human capital is become more familiar in many industries and management field. Human capital is the main man against the backdrop of diverse attitudes and behaviors that are centered on elements of cognitive (mind), affective (feeling) and psychomotor (physical). In the process of formation of personality, attitude and mentality, people are more heavily influenced by a belief system because of the sustained momentum of socialization experiences during her life since young. But at the same time, knowledge and expertise and the value entity with a variety of relevant factors in determining human attitudes and actions in the treatment of exercise are more responsibility for themselves, families, organizations, communities, religions, races and countries. In another word, the human capital management should be characterized the dimensions of tasawuf (mysticism which is purification of the soul) that religious values as the foundation and is also expressed in human governance. The question would then arise whether a manager who has a personality traits as a leader worthy to be a model in an effort to strengthening the human capital. Availability of many issues today that showed the existence of bias in the attitude of a leader of an organization so that a variety of communication problems between the leader of staff and this led to conflicts and the prolonged crisis that could eventually threaten the common aspirations. As we known, humans are created by the presence of important domains within the mind, emotions (soul) and physical. In a long sequence of time, men with high in the minds and thoughts are usually admired by all and made an idol of the diversity of life strategies and the creation of technologies that could shake the world. The ability of the constant in the power of intelligent thought possible that the ability of other was marginal triggered the empty spaces in a more profound nature and characteristics of emotion, soul and feelings. The gap exists between the mind and soul resulted in the progress of the past provides lessons for a thousand meanings, and refresh it back in the new rhythm and a new breath for common sense to be appreciated for generations to come. Therefore, emotional intelligence or EQ in the present must first had given special attention to the function and role in human life in order to improve the dysfunctional nature of the scenario. However, this discussion will be linked to emotional intelligence leader in the workplace with a human governance model from the perspective of spirituality model by Imam Al-Ghazali

\section{Purpose of Study}

The purpose of this study is to explore and discusses about the human governance of leader in the emotional intelligence elements through the model of spirituality. This study was investigating too about the behavior and affective of leader which have a significant impact on their style of leader and the way we discuss it is by the element of emotional intelligence and spirituality aspect. Then we will also see how the emotional and spirituality 
element among leader will be impact to their human governance at the workplace.

\subsection{Conceptual of Emotional Intelligence}

Emotions have quite a long discussed and studied since the first of many similar scopes in terms of function and importance, although not directly talk about the concept of emotional intelligence. Although all human mould beings are born has a heart and feelings, but not all dimensions of the heart is able to handle really is the nature of humanity in total. When the emotional focus as an important element in human life, so there was exist the term of emotional intelligence (EQ). The Oxford Dictionary of Current English Language (1999) also describes the emotions as well as a strong feeling in the manifestation of the instinct and the brain. While according to Oxford Advanced Learners' Dictionary (2000), state those emotions is a rather strong feeling and contain various kinds of feelings like hate, fear, jealousy, love, merry and sad, but there were also disturbances in the sense of an individual human being. According to Goleman (1995), emotional quotient (EQ) is the ability to monitor personal emotions and other emotions, to distinguish the good, and to use the information to help the mind and the actions of a person.

For Thorndike (1920), emotional intelligence is related to the concept of human social intelligence. Thorndike (1920) defines social intelligence as the human ability to understand and manage men, women and children to communicate effectively in human relations. He also has categorized the emotional quotient of two main parts, namely interpersonal (emotional contact with others) and intrapersonal (emotional connection with the relationship with yourself). Emotional intelligence can also be interpreted as a kind of social intelligence is responsible for controlling one, and a range of emotions, to discriminate against these emotions and use the information to control the thoughts and actions (Mayer \& Salovey, 1993:433). Based on the opinion of Mayer \& Salovey (1990), the interpersonal and intrapersonal emotional intelligence is categorized into five major domains that recognize the self emotional self-management, self-motivation, empathy and handling relationships effectively (Goleman, 1995).

\subsection{Emotional Intelligence by the Islamic Perspective}

In Al-Qur'an, has revealed much about the emotions associated with the human created by Allah SWT. Even in the Prophet's Hadith also mentions many different types of emotions that exist within an individual human, whether it is positive and negative emotions. If viewed from the perspective of Islam itself, emotional intelligence is more focused on the process of cleansing the heart and soul. Essential to maintain care not to foul and not damaged very much required in our religion. With a good heart, it emerged that both the value of emotional intelligence. Heart will be dirty when people commit sin so that it became black and dark hearts. Damage to the human soul and conscience will eventually lead to personality, attitudes and negative behavior that is inconsisten with the nature of the purity of human beings. As a result, people who do not learn anything from his life is said to have been suffered blindness in her eyes, but also deaf ears not wanting to listen to the teachings of the good. Clearly, the emotional intelligence is closely related to religious values. What's more it is linked to the spiritual nature of spiritual intelligence. The position of spiritual intelligence is in fact the highest level because it brings people maintain a relationship with God, while the intellectual and emotional intelligence will bring people to keep in touch with him, other humans and the environment. Allah Almighty also says in Surah Ash-Shams (91:8-10), which means; "Allah inspired the soul of wickedness and piety, and lucky for the purified, loss for the muss.

\subsection{Conceptual of Human Governance}

According Arfah \& Aziuddin (2009), human governance is a driving force for happiness, peace and tranquility. In the scenario world of management and administration, leading to the decisionmaking processes, human governance is an action that integrates the actions, processes, meanings, and the commendable results also showed that human governance matter is also a tool and means of achieving prosperity. According to them again, human governance is a question of integrity, about the turn Mohsen, always in a state of devotion to doing good. In a simple sense, integrity is closely related to human governance is also related to the question of religious and moral values and levels of ability to appreciate and practice good character even though no one is holding to the concept of goodwill who believe that God does not have missed seeing what people do. Good character is from the good qalb (heart) and the actual heart will be translated through behavior or personality of human. It has a close relationship with the internal problems that lead to affective and feelings, whether it is in line with the demands of universal values or not.

\subsection{Conceptual of Spirituality Model Of Imam Al- Ghazali}

Imam al-Ghazali was one of Muslim leader in the travel world of tasawuf (mysticism) and is also known as the Islamic Hujjatul with his full name was Abu Hamid al-Tusi al-Ghazali. He is a member of the Sufi, Ushul figh and Tasawuf book writer who has been to revive Islamic thought in the 5th century AH. Al-Ghazali highlight four terms in explaining the human soul is qalb (heart), ruh (spirit), nafs (soul) and 'aql (intellect or mind). Every word is contained in the Quran unless aql. However, it still exists in many forms and verse leads to the shows, and aspects of human thought as found in a particular surah (Zaini \& Syed, 2010). This view is further explained by Yusuf Al-Qardhawi (1998: 19) in Aminudin (2009) concerning the position of mind and thinking in the Qur'an that was repeated 49 times with an expression so that people need to think and think. Al-Quran and common sense to move in tandem in which the Al-Quran in guidance determining the science presented is true and beneficial (Sidek, 2004: 31) in Aminudin (2009). In Al-Quran, the inner regions of the spirit, heart, soul and mind that are not explained by one word only, eg the word nafs, which means soul. In addition to the word nafs, no other terms of the same qalb (heart) and aql (mind). Al-Quran does not call only in the form of a noun, but also in the form of the verb (Komaruddin, 2002 in Aminudin, 2009). Along with this discussion, the heart (qalb) specified by the Al Ghazali (1988) carry two meanings. First, it is a piece of meat located on the left chest. It was a meeting of all the nerve center of the blood throughout the body.

The second meaning refers to the implied meaning is more subtle and spiritual nature. It relates to the physical heart of the meaning of the first stand. However, al-Ghazali was great emphasis on the meaning of the second heart. It became the center of all desires, needs, ambitions and desires. All other members of the body at will as to whether he wants to do good or evil (Zaini \& Syed, 2010). There are spirits that are defined by two of the first meaning; the spirit is as a body that is a very fine substance that comes out of the room a human heart (Mohd. Azhar, 2009). It is central to the movement of all the blood vessels which then move into the human body such that the existence of the soul, and with the permission of Allah Almighty, then people will be able to breathe, move, heartless, seeing, hearing, and all movements of a human life. By relevance in medical physics, the spirit likened to a light from a lamp that illuminates the entire house is where Al-Ghazali gives an analogy that life is dependent on the spirit and the way light affects the body is assumed to be a lamp that emits light to the entire scope (Noor Shakirah, 2008). It is also defined as an element in the form of vapors emitted from the liver and carried to the brain through the pulse. Of the brain, it will spread to all parts 
of the human body through the pulse and were subsequently disclosed by the behavior. The second meaning of the spirit is then described by al-Ghazali that the spirit is a delicate nature of the man who can know everything and to understand the meaning. $\mathrm{He}$ also stated that the spirit is a difficult business in which the human mind cannot afford to think deeply. This is in line with the word of Allah, which means; "Say (O Muhammad), soul is includes in my business, and you are not given but little knowledge" (surah alIsraa: verse 85).

Intellect (aql) is the main thing made by God. Al-Ghazali was also a lot of sense to discuss the question of these things in his book. Intellect is the place where knowledge is developed. There was difference between the human minds with an animal like a light in the human heart that allows for people willing to accept science. There are two common meanings are very closely linked to alGhazali's discussion of the elements of the depth of the human heart. The first explains the meaning of the authority's knowledge called the heart (qalb) clearly demonstrated the fact that human. This item is in the Quran and Hadith which he defined as the power of human understanding to know the nature of things. If the 'aql as compared with the nafs, it is viewed as a power of vision. This is because the mind, people are willing to observe the things rationally through the power of vision that are willing to see things that can be seen while the third meaning is more to the nature of self in human beings themselves (Hamid Fahmy, 1990: Zaini \& Syed, 2010).

Lust is also an essential element in the strength of spirit that has two very opposite of the first strength is the strength of moral values and full of glory and goodness as loving, generous, caring and sincere. The second strength is the power of evil as ruffian, angry, vengeful, and agitators. Al-Ghazali divided the passion to some of the first stage is the desire of al-ammarah. Lust is not evil passions had elements of glory and goodness. Humans will do evil in the very extreme and ruthless elements of this event in the human soul. The second passion is al-mulhamah the desire that a combination of elements either bad or good, and unfortunately, passion, evil desire to dominate it will be good. Lust is the desire of al-lawwamah the third contains a combination of both good and evil elements. But the difference with al-mulhamah desire is where the passion, the desire of good over evil desire to dominate. There are desires that the fourth is al-muthma'innah the passion that has some kind of glory only. Certainly, they have their passion is indeed guaranteed by Allah to continue to go to heaven without going through any torture or checked in for a long time. Al-Ghazali was referring to the word of Allah, which means,

"O the calm soul. Come back thou to thy Lord with the satisfied heart and with acceptable. And entered into the congregation of My servants and enters into My paradise" (al-Fajr: verses 27-30).

Consistent with the above discussion, according to Al-Ghazali view based of al-Qur'an and Hadith, there are three major factors that influence formation of attitudes, personality and human personality, namely factors of heart, passion and intellect (al-Ghazali, 1974). Here is explained by these factors, starting with the heart. Liver is a description of medical physics is defined as a piece of meat that function to the blood circulation in the human body while the second meaning refers to the human heart as a spiritual center on the rational instincts. In determining the quality of the individual human heart, is seen to what extent the human heart is able to appreciate the minutes of Allah SWT. Thus, individuals whose hearts are not strong religious beliefs and religious practice are not in total, in fact in dire need of understanding to guide him in the act. Liver is said to be the heart of individuals 'qalbun'. This is very different from the individual quality of his heart 'lubbun' as the birth-induced liver (intuition) of these individuals are more rational and sincere in guiding and driving wise. In between, there are two types of heart which is 'fua'adun' the hearts of individuals who already have a strong belief on the teachings of God and strive to become a servant who believed and feared.

Humans are more willing to behave in a cruel and evil is a human individual is seen to function at the lowest passions of ammarah lust. For individuals who has the personality of noble, gentle, well pleased, grateful and appreciate also be viewed as 'the angel of life' as it serves the desires of mardiah lust in the second level high. Lust of kamilah may also only be attained by the apostles who have the capacity and self-maintained. On the whole desire is divided into seven levels. The composition of the lower passions of lust that is the highest is ammarah desire, followed by the desire of lawwamah, mulhamah, mutmainnah, radiah and the highest ranged is mardiah. However, ordinary people can achieve when such mutmainnah lust of human spirit can with stand series of libido and achieve peace. Quality is able to shape the desires of the individual personality of the man who is more rational and controlled.

Next is the sense of a special grace to His servants and as the intellect or mind is said to enable people to be able to form concepts, generalizations and interpretations. Clearly, the presence of mind is to enable people to think more systematically and rationally. AlGhazali insists that the quality of the human mind is divided into three different types of mind. Children aged two years, for example, to act according to what is seen. If the ball is covered with a cloth, the child will divert attention to other objects because the ball had gone out of his sight. Significantly there, mind the children work to what is seen alone. If the condition is also present among adult men, the idea that individual views are shaped from the past rejected such an abstract thing of sin and the reward. In this situation, make sense as it will be referred to as common sense is the least common category. For the individual human being is able to analyze and investigate a situation with a view to the root-cause of the problem and assess the consequences, it makes sense at this stage is common sense categories of reason is simple. But for the individual human being who can think more rationally based on the sincerity and strength of his faith, it makes sense that they can be classified as high-quality sense of mind tadabbur. Between the words of God which demands that the human sense is:

"Verily in the creation of heaven and earth, night and day change, and ships sailing in the ocean that brings things to benefit mankind and the revelation by God of the sky and the water turned the arid land with it and spread it all life, through the wind and the clouds subjugated between heaven and earth, that all the signs of Allah SWT for those who think" (Surah al-Baqarah: verse 164).

Imam al-Ghazali saw the development of character, personality and human personality encompasses all aspects of the individual that involve knowledge of religion, faith, worship, appreciation of the Quran, manners of life, family life, living, human relationships, ethics, morals and development soul and heart. According to al-Ghazali, Al-Khulq is steady and precise psychological atmosphere that translated into a simple act that rises with no need to think long. Mental atmosphere is the source of that act requires the actions of both, but if it appears to the contrary, the spiritual atmosphere was named as a bad character. Whatever definition is given, the human character building itself can be construed as a constructive character, personality and behavior with the goal of making people become more civilized, intellectual, moral-minded, persistent and progressive. The basis adopted in the developing character of a person that is based on what has been enshrined in the teachings of Islam which has been perfect from every aspect. Allah says in Surah al-Maidah verse 3, mean;

"I have perfected your religion for you and completed my favor upon you, and I have pleased Islam is a religion for you." 
In a study of the philosophical dimensions of the psychological context of Islam relating to the question of the human body and soul, Al-Ghazali with the description of spiritual models also have put the category in terms of psychology leading European psychologists of the 18th century. In conclusion, Imam al-Ghazali was to share perspectives on questions of character description (personality) and correlated with the heart that is based on the Qur'an and Hadith to the people of the world after many decades of perspective models of human spirituality. It is clear also stressed that from a clean heart to desire a reasonable level, a person will appear as an individual and moral character. Indeed, the description of the approach is spiritual and supernatural aspect is the absence of empirical evidence or statistical research or experiments, but the knowledge-based of the logic revelation and its relationship with various elements of the fact of creation should not be for us to reject outright.

\subsection{Frame of Application Needs of Spirituality Model towards Human Governance}

Moral question is the interpretation has clearly indicated that these elements exist in the soul cleansing that led to the positive characteristics and values are displayed in terms of behavior and should be applied in everyday life from generation to generation that it became a cultural harmony underlying pattern of life. It is quite clear; moral is formed from the inside and outside (Pahrul, 2010). Muslims need to look at emotional intelligence in terms of spiritual cleansing to be able to create a more moral nation through the strengthening of relations with Rabbul a'lamin (hablumminallah) In any organization, its first chairman was necessary to cope with the scenario of managing and administering a human need to highlight and interpret the needs of human nature that has soul, spirit, intellect and desire to be based on religious and subject to the law and the law of Allah SWT. If leaders fail in this first aspect, it certainly would have failed leader to govern the organization as a rule that involves both legal and organizational entity. At the same time, communication and interaction should also be formed with a harmonious atmosphere and this can be viewed through the bond of Islamic fraternity and good relations with fellow human beings and the environment (hablumminannas). The following discussion of human governance through some element of emotional intelligence from the eyes of the spiritual approach that focuses on the moral virtue derived from the purification of the soul (qalb), the spirit and the mind.

\subsection{Human Governance through The Intent Interest}

In formulating any measure, the individual must be started with the intention. Specific to the scenario in the organization, leaders must be set with a sincerer intention in advance to help guide the intention of working in the hearts of employees. Al-Ghazali in his entitled Ihya Ulumuddin sincerely says that the place is in the heart most closely related to the intent and purpose. The fact that faith itself is was based on responses from a variety of conditions. For example, if a person just to get the name of charity and feel pride, then it is a sincere intention of the language. However, if we give alms to the intention to seek the blessing of God and to draw closer to Allah (taqarrub), so that the true intent is of the sake of Allah SWT. From the perspective of Islamic spirituality, too, is supposed to be good intentions before doing something is to be motivated toward good behavior. Good intention alone has enabled us to get a reward from Allah, let alone if it do what it intention. But as a leader, it is necessary for the leader himself intends to carry out the work with sincerity and everything is as worship to Allah is the God of creator. Intend to do work for God will bring peace in the soul when all is done is full of patience, sincerity, and resignation is only the pleasure of Allah. Taqarrub elements is a need to emphasize to employees in the organization because of the emphasis on the fact that we are all slaves to God, and it is most closely related to the concept of monotheism and
Ubudiyah (sense of themselves are slaves of Allah). As word of Allah in Surah al-Anbiyaa ', which means verse 21;

"And We sent not a messenger before thee, but We reveal to him, 'Whereas there is no Ilah (right) but I, then all will worship Me."

Imam al-Ghazali also said that monotheism and Ubudiyah not only the beginning, but also the end and middle of every human being, like water for living things, like air to humans and the like spirit of life into the parts and the whole body or behavior in a variety of purposes (Sa'id, 2008). Certainly, the nature of the rabaniyyin is the highest station, even the nature Ubudiyah Prophet also mentioned in the event of Isra' Mi'raj and when the Quran was revealed by God at the same time shows that how Ubudiyah is a high-status people in front of Allah SWT. Ubudiyah is a known fact (ma'rifah) on the properties of God, worship Him, worship in accordance with the sharia's, give yourself totally to Him only, and always trying to improve ma'rifah, and the resignation of worship only to Allah SWT. So, the question of human governance by leaders in the workplace, it is supposed to start with the behavior of leaders who are able to correctly interpret the intent of the behavior of the honest and do the job just as God in the most important goal. The concept of monotheism and Ubudiyah have always emphasized to employees will also be indirectly motivated by the correct of intention before doing any work. If religion and God have been placed as a priority, leader would be effort to reduce the problem to invite each member to strive to achieve organizational objectives and organizational goals as well as govern the organization in general, where every employee understands the concept of work is worship and nurture a sense of Ubudiyah for God.

\subsection{Human Governance through the Integrity Interests}

Perfection and application of moral ethics instruction is to be a beautiful blend together to be appreciated in a community and it was similarly, examples and guidance from leaders in the workplace. Leader should be able to apply the good personality and the best model for its employees living and emulate. The success of the leader emotions that enable employees to handle these problems with more wisdom and parenting dimensions would produce a very dynamic effect but also help enhance employee selfrecognition. Therefore, it is necessary to translate the importance of practice is also leader of the integrity of the work that is closely related to the importance of honesty and trust in the reality and impact of an action. The Prophet Muhammad, which means;

"Surely honesty that led to welfare and charitable lead to heaven and for those who told the truth will be written on the side of God as being honest. Indeed, that fraud led to disobedience and disobedience brought to hell, and for those who told the lie will be written on the side of God that they are liar" (Hadith, Narrated by Bukhari \& Muslim).

Imam Al-Ghazali also describes the honest words (Siddiq) used in the six meanings such as: honesty in speech, honest in intent and desire, be honest in intention, sincere in fulfilling the desire, the honestly act and faithfully in the realization of all religious station. Thus, if an individual should act honestly in all six of this meaning, it will be referred to as Siddiq (a very honest person) and the level of honest like every human is different (Sa'id, 2008). In the reality of human life must work to make a living as a going concern and as its efforts to meet its obligations as servants of God on earth, the demand for honesty and integrity are necessary to be emphasized in any organization. 
Leader in the work place must first to practice integrity and would work as a religious faith (just for the sake of God) for the work to be more blessed by God and has always facilitated in every business. Emphasis is to be honest and trustworthy and adopt uncompromising integrity must always be distributed to employees so that they are also trained to be more integrity in their work, are always pleased and responsible. Certainly, the appreciation is based on faith and the teachings of the Qur'an and Hadith, the practice could be strengthened and enhanced the integrity of the organization for the prosperity and more blessings of ownership provision. In fact, the adequacy of the practice of integrity in the workplace will also be able to eradicate corrupt cases, work absenteeism, disciplinary problems and other problems detrimental to the work ethic. This can be overcome if all the leaders and workers will always hold the concept of emotional intelligence in terms of needs pure heart and soul cleansing is very necessary to be followed by practice for what is noble in life which is consisten with the treatment and will consistently be a good character is.

\subsection{Human Governance through The Motivation Inter-} est

In general, motivation is the process or factors (motives) that influence people to act. The psychological view of motivation as a process that gives rise to the conduct, maintain and channel behavior to the behavior of certain actions. Leaders and employees must to be smarter to motivate the negative emotions with a systematic method of thinking through the best sense of God's grace in solving problems while working to change the medium to a more positive emotion. The momentum of the self will certainly strengthen the emotions, mentality and personality to become more excited and motivated to face any situation but also able to find solutions that are more relevant when dealing with any problems through the exploration of a wise and prudent. In Islam itself, confirms that we have worked hard and tried as if we will live longer, at the same time we also need to diligently serve God as if we were to die tomorrow.

This expression should be a motivation to everyone if they can understand, appreciate and contemplate the meaning behind them. Al-Ghazali discusses the motivation for this question in terms of intention and desire to do something before (Sa'id, 2008). Whenever a person has a goal and vision to do something, and then followed that action will realize the good intentions that are targeted to become a reality. Every good deed will get a good response, so too is the opposite. Synonyms are also here, as Muslims are supposed to be our main goal is to become the servant of God who believed and feared by many applications that have been ordained practice. For with it we can find God in the hereafter, and opens tomorrow for the hijab to see Him in heaven. The world should not blind us well satisfied for the hereafter, we are also not blind eyes to see God the Almighty. Certainly, this fact is to be strong motivations for any further individual consistent educate the heart, soul and physical sense to always act, feel and think based on life acceptable to Him. With the strengthening of selfmotivation, the leaders and workers will be clearer with the direction and goals in life. Vision and mission in the struggle to achieve success will always be a platform based on the spirit of self that is never give up continuing. Motivated individuals who are symbols of people who strove to achieve the objectives of not abandon the question of personal ethics and moral values and universal symbol of the strength of character.

\subsection{Human Governance through the Reflection Inter- ests}

The question of human leaders to govern in the interests of the workers in terms of self-reflection is not only focused on the workers themselves but also on the leader itself. As leader of the necessary moral and have a high level of emotional intelligence, the leaders need to be constantly reflection himself every day for each treatment. Willingness of leaders to accept criticism even from his employees and trying to fix weaknesses enabling environment in the workplace will be developed with a more harmonious if there is pride and ego can destroy the fraternity in the organization. Al-Ghazali also explained that people who have bashirah 'sense' of the fact that God is always watching her and her will be reviewed at a later date is necessary also to keep themselves and them reflect in all circumstances because anyone who reflect vetted him before, it will lightly be reckoning on the Day of Judgement. Certainly, there is nothing that can help us in the Hereafter but the absolute obedience to Allah SWT. Thus, Allah has ordered Muslims are always patient and always murabathah (get ready) as well as always reflect them. Allah says in Surah Ali Imran, verse 3 , which means;

"O ye who believe, be patient and strengthen your patience and remain ready..."

Empathy is a feeling and the ability to comprehend and understand the feelings or emotions of others in greater depth. The strength of empathy would exist in a person if it can be practiced murabathah and continuous self-reflection. Quite clearly the importance to practice self-reflection is a greater benefit for themselves or other individuals that could bring down the walls of arrogance as well as to keep in mind that all men are equal who came to wander the earth, which is where we serve while and prostration to Allah Almighty that one.

\subsection{Human Governance through The Insane Interests}

In discussing the question of courtesy as a true Muslim, most relationships must be maintained and strengthened in advance by every Muslim is a human relationship with God the creator. Loving God is most great love for Muslims and as a token of love to God, is always encouraged us to perform all and leave all prohibited. Allah the Exalted has always wanted His servants to do their best in this life for the supply of life in the hereafter. And therefore, He said that man created by God is to be a caliph in the earth. Along with the fact that goodwill is the vicegerent of God, it is very necessary for human-like responsibilities to see God and if God cannot see though, it is necessary to believe that Allah sees His servants. So, if the leader and the employee has to feel compassion in him, certainly many problems in the workplace can be solve in fact they will feel the sweetness of sincerity in the works when the concept has always held that it is a religious work.

\subsection{Challenges and Hopes}

The result of this discussion, it is clear to us that it is an interest to every leader in any organization to be competent with the emotional and spiritual intelligence as a similar high to belong to the soul, spirit, intellect and passion that a true Muslim dominance in the direction as well as bringing the personality and noble character of a desire to create workers who also have mental and moral development that is consistent with the demands of Islamic law. Quite clearly, this discussion thread highlights the challenge of good governance including human psychology to apply the elements of Islam in the organization where the availability of the elements associated with the study of human behavior and affective. Certainly, we also need to give priority to internal moral compass and highlighting human tenets of God in governing human first before we talk about rules and laws are drafted by the organization of the human self. Hope also for the establishment of national human intelligence not only has a strength in terms of knowledge, but should also be lined with people who have emotional and spiritual intelligence as it is the strength of the affective stable and able to face challenges with perseverance and patience. 
In addition, possession of spiritual intelligence which is traits of spirituality allows Muslims to always maintain a relationship with God as a spiritual force that promises peace of mind and the ability to forge lasting relationships with fellow human beings and the environment. We certainly hope our world does not only significant with ownership of all the best facilities in the world (first class facilities) and the economic dominance of the dominant (capitalist economy), but in fact had dwindled humanitarian values but lack of universal values. This will enable us to lose selfvalues, self-esteem and loss of function as the people who are willing to sacrifice for the country in the name of religion, race and national sovereignty because of globalization. What is clear is different from the teachings of Islam because in Islam, human life must always be boundaries and limits for a variety of wisdom for the good of all. Even the simplicity of Islam has never received a life of extreme, oppress other people, terrorize and destroy. Instead of emphasizing the spiritual life in Islam is a peaceful, compassionate, respectful and harmonious. And that is where there is real wisdom of good relations between man and God and the human relationship with fellow human beings or the environment. The concept of moderation in Islam also emphasized that we do not become a man of excess-over in every way compared to the capitalist system is always a negative impact across countries and borders. These challenges, if not tackled, it is possible we must pay the very expensive capital to make progress due to the expense of the country of universal human values that has triggered public minded, spirited and personality third grade. Appreciation of the teachings of the already integrated guiding people to have a noble character should be practiced and do it in everyday life in the grip of each individual human being as well as the possession of intimate knowledge and experience in implementing sustainable excellence Muslim civilization. The Prophet Muhammad said, which means is; "You cannot help everyone with your wealth, but give them space (happiness) with a sweet face (smile) and good character" (Hadith narrated by Muslim).

\section{Conclusions}

Overall, the human governance of people at work by the leaders is necessary to constantly review and study of emotional intelligence and spiritual aspects that are explored through the perspective of a spiritual approach and the value of tasawuf. Leader has an important role to implement emotional intelligence and spiritual elements in his behavior to become habitual and can be embraced and emulated by both the followers to achieve the integrity and quality of work is based on the concept of compassionate and religious life. By having the robustness of the emotional and mental aspects, each employee will also have the personality and behavior that is consistent with the demands of human nature to live harmoniously in all circumstances. Emotional stability will enable employees to work with leaders to produce a better quality of work output without priority to the question of wages or benefits, but more motivated by sincerity and integrity and responsibility. In conclusion, this connection makes the rhythm that is based on spiritual psychology and spirituality of the leaders and workers to become more dynamic and capable of achieving a healthy lifestyle.

\section{References}

[1] Al-Ghazali (1988). Ihya' Ulumuddin. Jilid 1\&2. Edisi Ke 3. Translated by Ismail Yakub. Singapura. Pustaka Nasional Pte. Ltd.

[2] Al-Ghazali (1974). Mishkat Al-Anwar. Terjemahan Abdul Majid Khatib. Kelantan:Pustaka Aman Pr.

[3] Aminudin Mansor Ph.D (2009). Konsep 'Akal Budi' dalam Sastera Melayu. Jurnal ASWARA (Akademi Seni Budaya dan Warisan Kebangsaan). Bab 2.

[4] Arfah Salleh \& Aziuddin Ahmad (2009). Human Governance : A Paradigm Shift in Governing Corporations. Kuala Lumpur : MPH Publishing.
[5] Goleman, D. (1995). Emotional Intelligence : Why It Can Matter More Than IQ. New York : Bantam Book.

[6] Mayer, J. D., \& Salovey, P. (1993). What is Emotional Intelligence? In P. Salovey, \& D. Sluyter (Eds.).

[7] Mohd. Azhar Abd. Hamid, Editor (2009). Panduan Meningkatkan Kecerdasan Emosi. Kuala Lumpur: PTS Professional.

[8] Noor Shakirah Mat Akhir (2008). Al-Ghazali and His Theory of the Soul : A Comparative Study. Pulau Pinang : Penerbit Universiti Sains Malaysia.

[9] Oxford Advanced Learner's Dictionary of Current English (2000). Oxford: Oxford University Press.

[10] Sa'id Hawwa (2008). Kajian Lengkap Penyucian Jiwa:Tazkiyatun Nafs. Intisari Ihya'Ulumuddin. Jakarta: Pena Pundi Aksara.

[11] The Oxford American Dictionary of Current English (1999). Oxford: Oxford University Press.

[12] Thorndike, E.L. (1920). A Constant Error In Physical Ratings. Journal of Applied Psychology, 4, 25.

[13] Zaini Said dan Syed Muhammad S.A. (2010). Pemikiran al-Ghazali $(450 \mathrm{H}-505 \mathrm{H})$ in the field of Islamic Psychology. Universiti Sains Malaysia. Papers presented at the 2010 convention of the National Counselling. City: Universiti Malaysia Terengganu. 